\title{
From Types to Populations: A Century of Race, Physical Anthropology, and the American Anthropological Association
}

\begin{abstract}
In the 1960s, U.S. physical anthropology underwent a period of introspection that marked a change from the old physical anthropology that was largely race based to the new physical anthropology, espoused by Washburn and others for over a decade, which incorporated the evolutionary biology of the modern synthesis. What actually changed? What elements of the race concept have been rejected, and what elements have persisted, influencing physical anthropology today? In this article, l examine both the scientific and social influences on physical anthropology that caused changes in the race concept, in particular the influence of the American Anthropological Association. The race concept is complicated but entails three attributes: essentialism, cladistic thinking, and biological determinism. These attributes have not all been discarded; while biological determinism and its social implications have been questioned since the inception of the field, essentialism and the concomitant rendering of populations as clades persists as a legacy of the race concept. [Keywords: race, essentialism, physical anthropology]
\end{abstract}

$\mathbf{T}$ HE EVENTS SURROUNDING THE PUBLICATION of Carleton Coon's The Origin of Races in 1962 reflected a major change in U.S. physical anthropology. Coon suggested that five major races of humans evolved in parallel from Homo erectus at five different times and at different rates. He further suggested that each racial lineage crossed the sapiens "threshold" at different times in prehistory and implied that the length of time each had been in the sapiens state was correlated with the level of "cultural achievement" of different racial groups. Coon contended that Causcasoids and Mongoloids crossed this threshold considerably earlier than Africans (Negroids and Capoids) and Australians (Australoids), a claim that clearly had social implications.

Race had held immense importance within the field of physical anthropology during the time leading up to the publication of Coon's work. At the emergence of the subdiscipline, race was the major theoretical foundation of anthropology; physical anthropology was virtually synonymous with the study of race. In 1902, at the inception of the American Anthropological Association (AAA), most anthropologists considered "race" to represent the way the human species was internally subdivided. Essentialism was implicit in this idea; a race was thought to represent a natural category with unique features that defined the essence of that category. ${ }^{1}$ It seemed obvious to many anthro- pologists that these biological subdivisions corresponded to the social meanings of race, a notion that linked physical and behavioral characteristics. This link between the components of an essence provided the basis for the biological determinism prevalent in the racial thinking of the time. Throughout the 20th century, race also had an evolutionary component. Races were effectively thought of as clades. Different essences were explained as a product of poorly understood evolutionary processes, as exemplified by Coon's notion of independently evolving racial lineages.

The discourse Coon's book spawned contributed to currents within the field that ultimately forced an end to the old physical anthropology centered mainly on the race concept and helped usher in the new physical anthropology, espoused by Sherry Washburn, which had been developing throughout the 1950s. The new anthropology was eclectic (incorporating various subjects from primates to genetics) and was an evolutionary science, whose populational approaches were incompatible with the essentialism central to the race concept. The Origin of Races brought to a head the rifts within physical anthropology as a discipline, the tensions between the subdisciplines of anthropology, and discussions about the role of anthropology in the public arena.

The AAA's reaction to the book was decisive. Washburn, then president of the association, delivered a scathing 
address denouncing the book around the time of its publication at the AAA Annual Meeting in Chicago on November 16, 1962. The published version (Washburn 1963) is much less harsh, focusing on the limited use of race as a valid object of study and the lack of scientific support for any claims of racial inferiority. Public denunciation of Coon's ideas seemed necessary; segregationists were already using them to bolster their arguments. There were a variety of responses from the scientific community. Statements on race were issued by both the AAA and the American Assoctation of Physical Anthropologists (AAPA). Several edited volumes appeared throughout the 1960s critiquing the race concept. In 1966, Margaret Mead and Theodosius Dobzhansky organized an Amertcan Association for the Advancement of Science (AAAS) symposium meant to deliver the scientific voice against a popular racism based on "misinformation" and "evil myths" about race. As embodied by its organizers, the symposium represented an alliance between Boasian cultural anthropology and evolutionary biology, including diverse perspectives from within anthropology, genetics, ethnology, psychology, and sociology. With few exceptions, most anthropologists had become opposed to hereditarian claims about race and intelligence, and many were now skeptical of the race concept itself. What became clear by the mid1960s was that race was no longer a unifying concept in mainstream physical anthropology, just as it had ceased to be a unifying concept for anthropology as a whole since Boas's work on race a half century earlier. In physical anthropology, race was now a divisive concept. Although Washburn had published his ideas about the new anthropology earlier, this period marked a turning point in the discipline, with greater institutional introspection on the race concept. Some have even argued that it marked the demise of the race concept.

Several factors influenced changing views about race within physical anthropology during this time. First, social factors prompted scientists to challenge assumptions of biological determinism and intellectual inferiority associated with the race concept. The Holocaust in the 1930s and 1940s and the controversy surrounding school desegregation in the early 1960s may have been the most important examples. Another component of social pressure resulted from the relationship between anthropology and governmental interest in race and racial inequality, an interest that had promoted the "racialization" of U.S. anthropology in the first place. Second, the race concept itself was challenged by the populational principles espoused in the modern synthesis; evolutionary ideas were incompatible with the essentialist foundations of the race concept, and alternative views of population and clines, based largely on understandings from population genetics, led many scholars to consider race an invalid tool for understanding biological variation. Finally, the evolution of U.S. physical anthropology, from its emergence as a subfield to the present day, has been influenced by its relationship with the rest of anthropology-specifically, four-field an- thropology as embodied by the AAA. It is interesting that as early as 1894 , a quarter century prior to the emergence of physical anthropology as a true subdiscipline, 'Boas began to challenge the race concept. By the time physical anthropology clearly emerged in the 1920s, Boas's followers held some of the most powerful positions within U.S. anthropology and were a dominant voice in the AAA. Therefore, the racial physical anthropology that was rejected in the 1960s developed within a broader anthropological context that had been grappling with the race concept for years; parts of that community already questioned race, and the AAA had been involved in struggles over the issue of race between anthropology and government policies and funding, as well as struggles between anthropology and other sciences. The rejection of race in the 1960s was not so new; it was a part of the heritage of physical anthropology within U.S. anthropology.

This history suggests that the race concept has no remaining legacy in physical anthropology. What actually changed? Is the race concept really dead? What elements of the race concept still persist and influence physical anthropology today? In this article, I address these questions, investigating them within the context of the scientific and social influences on mainstream physical anthropology that were a major force in the evolution of the race concept. I argue that some elements of the race concept were in fact rejected, but that others remain, subtly influencing our views of what we today term "populations."

\section{THE ATTRIBUTES OF THE RACE CONCEPT}

The race concept that was examined and rejected by so many in the 1960s includes assumptions about the cause and nature of geographic and other kinds of variation. The history behind these assumptions has helped create the concept that we grapple with today. Although for the last 100 years the race concept has been thought about in quasi-evolutionary terms, its most fundamental elements are essentialism, clades, and biological determinism. These attributes are clearly related, and all of them have informed the theories about human variation in physical anthropology. The race concept has changed, yet these attributes of race have not all changed together. While biological determinism and its social implications have been questioned since the inception of the field, essentialism and the concomitant rendering of races as clades have been less amenable to change.

\section{Essentialism}

The races defined by the Western race concept were codified by Linnaeus (1758) and by the definitive 10th edition of Systemae Naturae, in which he described five subspecies of humans, listing for each type both the morphological and behavioral characteristics that were considered a part of the essence of the category. These were implicitly (and explicitly) understood to be part of the intrinsic biology of the race. European prejudices were clearly incorporated 
into Linnaean typologies and taxonomies integral to the natural history tradition. From its very inception, the race concept embodied both essentialism and biological determinism.

In many cases this essentialism (and the natural history context to which it applied) rendered thinking about race very similar to thinking about biological species. This is exemplified in the polygenism so prevalent in the U.S. and French schools of thought that dominated much of anthropology for the first half of the 19th century (Brace 1982; Stanton 1960; Stocking 1968; Wolpoff and Caspari 1997).

Even after the widespread acceptance of evolution and many elements of Darwinian theory, a form of polygenism continued to thrive because evolutionary scientists retained an essentialist (and racial) perspective. Taxonomic categories, including subspecific ones, continued to be conceptualized as discrete groups, while the essences of the categories were explained as products of separate evolutionary histories. Races, like species categories, were depicted as branches on an evolutionary tree, whose differences could now be explained through their independent evolution, at different rates.

\section{Clades: Evolutionary Essentialism}

Conforming to the Darwinian notion of the common descent of all species, tree models became appropriate models for diagramming the relationships between species. After splitting from a common ancestor, two daughter species are reproductively isolated by definition and represent different branches of a phylogeny. Therefore, intuitive essentialism and older tree metaphors did not impede understanding of evolutionary processes at the species level, because the categories are discrete. However, the story is quite different below the species level, because branching cannot accurately reflect relationships between groups that exchange genes.

The essentialist link between depicting variation between species and variation within the human species was nowhere clearer or more influential than in the works of Ernst Haeckel. Haeckel used evolutionary trees both to describe the place of humans in the natural world and the relationships of human races within the human species. This had unfortunate implications for understandings of human variation. As Linnaean taxonomy was "evolutionized" and relationships among taxa expressed in terms of evolutionary trees, human races, like species, became branches (or twigs) on the tree, each with its own definable essence. This approach provided scientific explanations for human differences; human groups were effectively species on a smaller scale, whose differences could be accounted for through independent evolution.

Throughout the 19th and 20th centuries, the use of phylogenies to characterize human relationships in sociopolitical spheres provided the conceptual underpinnings of Western racial classifications. They provided jus- tification for "interracial competition" (Keith 1936), the basis for claims of the biological inferiority of social classes, and supported unjust social institutions ranging from slavery to various eugenic policies and the applied biology of Nazism (Gasman 1971; Stein 1988; Wolpoff and Caspari 1997).

The assumption of monophyly implicit in tree metaphors was made explicit with the general concensus that tree branches are clades, defined as monophyletic groups. A monophyletic group includes an ancestral taxon and all its descendents; clearly, races are not monophyletic and their depiction as clades is inappropriate. Yet tree branches are the underlying representation of race as a natural category, and of the evolutionary relationships between races. This construction underlies much of the thinking present throughout the history of U.S. physical anthropology.

\section{Biological Determinism}

Biological determinism is implicit to the race concept, and it is this component that has been most ardently addressed by the field because of its obvious social implications. In the 1960 s, biological determinism was a focal point of important current issues (in particular, school desegregation in the South), and it was because this attribute was at the center of political discussions that many in the anthropological community of the 1960 s found it important to address.

Nineteenth-century anthropology embodied both a racial thinking and evolutionism that explained cultural variation. At the Turn of the Century, virtually all social scientists were evolutionists, holding the idea that primitive races and their cultures represented stages in evolutionary history or branches of different lengths on an evolutionary tree. Different scholars tied biology and culture together in different ways: some were more deterministic than others, some saw biology as influencing cultural change, others like Lewis Henry Morgan (1877, reprinted in 1964), for example, thought culture affected biological change in the brain, in a Lamarckian sense. However, biology was usually considered the determinant of cultural differences. Anthropology, as it was practiced throughout much of the 19th century, was a single biocultural discipline, with race linking the components. Franz Boas severed this connection for U.S. anthropology, and while not all anthropologists agreed with him, he and his followers forced a kind of introspection-biological (racial) determinism of cultural differences could no longer be accepted as a blanket assumption in U.S. anthropology.

Biological determinism is not a necessary part of racial typologies and can be rejected without the rejection of the race concept as a whole. Throughout the history of the AAA, many anthropologists questioned the validity of racial determination of cultural capacities without completely rejecting the race concept and its underlying essentialism. Nevertheless, in general, the biological determinism of the race concept was deeply entrenched in anthropology as a 
major assumption of racial studies, and in Europe, racial anthropology was a major component of anthropological thought.

\section{U.S. PHYSICAL ANTHROPOLOGY IN THE CONTEXT OF THE AAA}

In the United States, ironically, given the influence of the earlier "American School," race had become somewhat less important than in European anthropology. Because of its emergence within (or in some cases beside) the broader anthropological tradition embodied after 1902 by the AAA, physical anthropology always represented more of a struggle between racial (i.e., those who focused on race) and nonracial elements-or should I say "less-racial" elements, because the race concept really underlay all thinking about human variation. To some extent, the new physical anthropology espoused by Washburn represented a realliance with the Boasian parts of anthropology that had questioned the assumptions of the race concept since the 1890s.

\section{Boas}

The story of race in U.S. anthropology (including physical anthropology) cannot be discussed without reviewing the role of Boas and the AAA. This has been treated by a large number of Boas scholars (to name a few: Cole 1999; Stocking 1968; Williams 1996), and I only briefly outline these relationships here to underscore the professional and political tensions affecting physical anthropology as it emerged as a subdiscipline.

Until the 1920s, there were really no U.S. degrees awarded in what would be specifically considered "physical anthropology." Nevertheless, race and racial assumptions still played an important, if secondary, role in anthropology. The field focused on Native American ethnology and archaeology and was descriptive; therefore, even while race may have been considered a cause of cultural variation, it was not emphasized. The pre-Darwinian polygenist American School of Samuel Morton had no students, and although the polygenist zoologist Louis Agassiz produced Fredrick Ward Putnam, who had a fundamental influence on the development of anthropology in the United States, Putnam's interest was archaeology, not race.

As anthropology emerged as a profession at the Turn of the Century, a commitment to Native American studies and the idea of professionalization (i.e., training in anthropology rather than related disciplines, or worse, none at all) was what held the early association together, in spite of early divisions between the "Washingtonians" and "Boasians" along this very line (Stocking 1968). Boas was responsible for the four-field training of many early Ph.D.s in U.S. anthropology, even those from outside his home institution (Columbia). Unlike the European model for anthropology, Boas thought training in anthropology should include all subdisciplines, as did his own research. At Harvard, Putnam concentrated on archeology, the fo- cus of most of the 15 Ph.D.s Harvard produced between 1894-1919. Yet, many of these students also trained under Boas in ethnology, linguistics, and physical anthropology (Cole 1999). Boas was instrumental in the training of Harvard students such as Roland Dixon (who was later to become an influence on Earnest Hooton's racial thinking) as well as his own famous descendents from Columbia. By 1926, Boas's students (or sympathizers) would head every major department in the country (Stocking 1968).

It is sometimes forgotten that Boas was a practicing physical anthropologist early in his career, probably the only one training students in the United States at the Turn of the Century. In 1894, Paul Topinard (the preeminent French anthropologist of his time, and student of Broca) wrote that Boas was "the man, the anthropologist, I wished for in the United States" (Stocking 1968:166).

Boas received his Ph.D. in physics in 1881 but by that time had become a geographer. Previously untrained in anthropology, he sought guidance from Adolph Bastian in ethnology and Rudolph Virchow in physical anthropology before leaving Berlin for Baffin Island. Boas much admired Virchow, who trained him in anthropometrics (Cole 1999; Stocking 1968). Like Virchow, Boas was interested in physiological processes and never became a Darwinian (i.e., selectionist), although he did recognize common descent and human evolutionary relationships to the natural world. Like many others of his time, Boas had Lamarckian ideas (see Wolpoff and Caspari 1997: ch. 8) and never understood selection. He accepted the view of many German scientists that selection could only effect small changes (Kinkerlitzchen, as Franz Weidenreich called them), not large ones. Moreover, and, perhaps, more importantly, Boas considered Virchow's most significant legacy to be the organization of the field in Germany, and, later, Boas consciously sought to be a similar figure in U.S. anthropology (Stocking 1968).

In the United States, Boas continued to make contributions to physical anthropology, which he recognized, as did everyone at the time, as racial studies. However, instead of accepting the assumptions of the race concept, he treated them as objects of inquiry. He wound up rejecting biological determinism rather early in the game, and, later, his work questioned the validity of human types, thus challenging the essentialism at the core of the race concept. However, he never really relinquished essentialist notions of major races-broad geographic entities-even as he questioned the validity of human types for smaller racial categories, such as various nationalities (e.g., "Nordics" or "Alpines").

His strongest contributions to physical anthropology were statistical, which he applied to studies of metric human variation. He was very interested in the new biometrics being advanced by Francis Galton and Karl Pearson, with whom he corresponded, and he developed his own methods of analysis as well. A major outcome of these studies was his appreciation of the importance of variation, which he used later to critique the idea of racial types. This can 
be juxtaposed with Hooton's use of Pearson's biometrics years later, which he used less critically to delineate racial types. Hooton influenced the development of a race-based physical anthropology in the United States; Boas and his legacy contributed to its demise.

By the time Boas came to Columbia in 1896, he was deeply concerned with questions of race and had researched problems of variation and change. He was already developing his ideas of relativism, sparked by his 1884 expedition to Baffin Island, and by then had largely rejected the idea that race determined cultural achievement. As early as 1894, he explicitly rejected racial determinism of culture: "Historical events appear to have been much more potent in leading races to civilization than their faculty, and it follows that achievements of races do not warrant us to assume that one race is more highly gifted than another" (Boas 1894:303).

He thought physical anthropology was important in understanding historical relationships among peoples, but even accepting races as "real," he recognized the importance of environment and history as influences on human biology and behavior. Boas was interested in growth and development as a critical part of physical anthropology, especially the conditions (environmental and hereditary affects on growth) that influenced the modification of inherited form. Prior to moving to Columbia in 1896, he initiated a study of Worcester schoolchildren in which he statistically demonstrated the problems with inferring longitudinal information from cross-sectional studies (and, thus, advocated for longitudinal studies in growth) and emphasized for the first time the importance of variation in tempos of growth. Thus, before the Turn of the Century, he was looking at human variation in nonracial ways, more interested in the impact of the environment (including culture) on biology than the affect of biology (race) on culture.

Boas investigated American Indian racial issues for the British Association for the Advancement of Science. He looked for relationships between heredity and environment underlying physical differences between reservation and nonreservation-dwelling Indians of the North Pacific Coast. He also looked at problems of racial admixture in "half-blood" Indians, rejecting polygenist assumptions of reduced fertility in racial hybrids. In these "mixed" populations, he also examined variation in cranial proportions, including facial breadths-where he noted the distribution was bimodal and not normal. In these and other studies, averages did not represent the "type." He later undermined the concept of "type," questioning its meaning: If averages did not represent the "type," what did? What was of interest was the distribution of traits, not the conformation to types or the creation of new, intermediate types in the case of interbreeding that was critical to the race concept. His most famous work regarding race was performed between 1908-10 on head shape in U.S. immigrants, funded (somewhat ironically) by the U.S. Immigration Commission, which was seeking a scientific basis to re- strict immigration. In a study of over 18,000 immigrants, he found changes in head form that undermined the dogma of the stability of racial types and the European focus on head shape as a major indicator of race. He could not explain the causes of change, although he considered them in some way "environmental" and, as an empiricist, argued that what was important was the documentation of the change itself. Through his work on racial questions, Boas challenged both biological determinism and the nature of racial categories, two critical components of the race concept. These challenges were a central part of anthropological thinking in the U.S. before Hooton started producing Ph.D.s in physical anthropology.

\section{"Racializing" Physical Anthropology}

Both governmental and private forces promoted the renaissance of the "science of race" in U.S. anthropology during World War I, running counter to the traditions developing in much of U.S. anthropology. However, there were also tensions between Boasians and other, at the time, smaller factions of the AAA who were sympathetic to the anthropologists associated with Washington institutions (Stocking 1968). It must be remembered that until Hooton started producing Ph.D.s at Harvard in 1925, there was no specific training in physical anthropology in the United States. Only six U.S. Ph.D.s in physical anthropology had been awarded prior to 1925-five of these from Harvard, trained by specialists in other disciplines. Aleš Hrdlička, the founder of American Journal of Physical Anthropology in 1918 , and AAPA in 1928, had no students in his position at the National Museum of Natural History.

During the second decade of the 20th century, many scholars who claimed to represent physical anthropology were actually eugenicists from other disciplines (that claimed scientific superiority to anthropology), and some were very powerful in the U.S. scientific political structure. These included members of the Galton Society, which was dedicated to the study of racial anthropology, such as the paleontologist Henry Fairfield Osborn (then president of the American Museum of Natural History), and the biologists Raymond Pearl and John C. Merriman (head of the National Research Council [NRC]). Many in the anthropological community saw them as a threat; they were racial determinists with a political agenda, and the Boasiandominated AAA did not accept them as anthropologists.

There was clearly a need for physical anthropologists trained within anthropology. This dearth became very apparent when the National Research Council sought to form an anthropology committee, which was to deal with physical anthropology and eugenics. Aside from Hrdlička and Boas, there were few physical anthropologists recognized by the AAA to serve (Stocking 1968). Madison Grant and Charles Davenport, ardent racists and eugenicists, founders of the Galton Society with strong political agendas and ties to Washington, served on the original committee. While the AAA refused to recognize Grant or Davenport as 
anthropologists, there remained enormous pressure on anthropology to "racialize," both from the government, which had become increasingly interested in restricting immigration on racial grounds, and from the eugenic interests controlling other major funding sources. Members of the Galton Society included the heads of institutions that had been (or potentially could be) important sources of anthropological funding. By the 1920s, funding increased for studies of race and racial psychology. U.S. anthropologists responded to this funding increase and to criticisms that they neglected biology and the racial makeup of the U.S. by expressing more interest in physical anthropology. Ironically, several of Boas's students (e.g., Mead, Herskovitz, Klineberg) were funded by NRC fellowships in the biological sciences for work that supported the cultural basis for racial differences, and Boas himself exploited these sources for his own work on race. Other students of Boas, such as Alfred E. Kroeber (and Roland Dixon), as well as more conservative non-Boasian elements of the anthropological community, also became more interested in physical anthropology, placing the race concept and eugenics at the focus of the emerging new physical anthropology.

\section{Hooton}

Earnest Hooton was one of the most influential ftgures in physical anthropology (Giles 1999). He was a professor at Harvard from 1913 until his death in 1954 and was responsible for training virtually an entire academic fteld, spawning several generations of students when few other universities offered physical anthropology as part of their curricula. Hooton's Ph.D. (in 1911 from Wisconsin) was in classics. He had little background in anthropology, and it took some time to get his program off the ground, but starting in 1926, a flood of Ph.D.s in physical anthropology emerged from Harvard. Within a few years, physical anthropology was a major part of U.S. anthropology, and this was reflected in AAA membership and the development of the AAPA.

Race studies came to be the focus of Hooton's career, but he formed his ideas about race and physical anthropology in general after he came to Harvard. His work was typological and manifested, like Haeckel's, as an "evolutionary polygenism" (Wolpoff and Caspari 1997). Hooton's Harvard colleague, Dixon, influenced his views on race; Hooton's 1931 classification is very similar to Dixon's 1923 classification.

The polygenism of Hooton and Dixon was complicated, grounded in the belief in once-pure races that had separate evolutionary histories. Like many other scientists with fundamentally polygenist ideas, they understood that present human variation could not be accommodated within a few racial types. Hooton thought that the complexity of human variation could be accounted for through interbreeding between once-pure primary racial groups that relatively recently underwent a secondary race formation stage and then a tertiary stage-in each stage, hybrid races formed from the preexisting ones. Thus, they argued, pure races existed and persisted into the present, but secondary and tertiary races formed more recently in human evolution through hybridization. Hooton's views were still essentialist; he believed in "pure" races, but he realized that a few racial types could not account for real observable variation.

Hooton's thinking about race had all the attributes of the race concept; he was an essentialist, he explained the essence with evolutionary branches, and he was a biological determinist as is clearly shown in his eugenic writing (Hooton 1937, 1939; Wolpoff and Caspari 1997). Given this, Hooton's views on racism could appear paradoxical (Wolpoff and Caspari 1997). While he believed in races, and even in "racial character," he was more active than most members of the academic community in antiracist activities, entering into a relationship with Boas that Barkan termed "the frustrated antiracist campaign of an odd anthropological couple" (1988:182). After many attempts to mobilize the academic community against racism, Boas turned to Hooton, who sent a statement he had authored to seven leading U.S. physical anthropologists outlining his view on the state of scientific knowledge of race differences. Among other things, he concluded that a correlation between physical features and mental ability had not been demonstrated and that there was insufficient scientific evidence to assign evolutionary ranks to races. Only Hrdlička would sign it. In 1936, Hooton then published his own "Plain Statement about Race" in Science, speaking against the racism underlying Nazism. In 1940 , as Hooton realized the futility of attempts to organize even the AAPA against racism, his student William W. Howells asked him what could be done. He replied: "Not only has the horse been stolen, but the barn has also been burnt" (Barkan 1988:203).

It is hard to overestimate the importance of Hooton to U.S. physical anthropology. Hooton's thinking on race was adopted by some of his students, rejected by others, but in either case, it strongly influenced subsequent generations of scholars because it limited their understanding of different ways of interpreting intergroup relationships. Even students such as Howells, who largely rejected Hooton's polygenism, inherited essentialist views (Caspari and Wolpoff 1996; Wolpoff and Caspari 1997). For instance, Howells was so conditioned by polygenic models that he did not interpret Franz Weidenreich's polycentric model of human evolution as a network, as it was originally presented (Weidenreich 1946). Following an initial exchange in the American Anthropologist (AA) (Howells 1942; Weidenreich 1940), Howells described Weidenreich's ideas as a polygenic tree (the "candelabra"). Even after diagrams of the trellis appeared (Weidenreich 1946, 1947), Howells continued to depict it as a candelabra in numerous secondary sources and textbooks throughout his career (e.g., Howells 1959 , 1993). It may be that Howells was in part reacting to the polygenism of R. Ruggles Gates, a racist plant geneticist 
who derived support from both Hooton and Coon, thinking Weidenreich shared these views (Gates 1944; Wolpoff and Caspan 1997). But Weidenreich (1946) specifically disavowed Gates's polygenism, and the candelabra Howells described was actually more like Hooton's model, and not Weidenreich's. "Tree-thinking" permeated physical anthropology; like Howell's depiction of Weidenreich's trellis, most scholars saw the "candelabra" as a reasonable simplification (perhaps an oversimplification) of a trellis, but one that represented the same processes. Depictions of gene flow were ignored-a legacy of the race concept.

Nevertheless, although very influential, Hooton's brand of race science did not permeate physical anthropology in the United States for long. It was never the overwhelming tradition that it had been in Europe, and his students, only a single generation later, were responsible for the new physical anthropology that disavowed the importance of race. Washburn, the most well-known among these, actively rejected the racial thinking of his mentor; it is not surprising that Washburn's first job was at Columbia, where he joined those predominantly influenced by the Boasians, including Ashley Montagu.

While few of his students shared Hooton's eugenic fervor, many of them continued his focus on race and human variation, at least for a while. Some, such as Stanley Garn and Coon, focused on problems of race definition, the number of different races, and problems of race formation (e.g., Brues 1972; Coon et al. 1950; Garn 1957, 1962). These researchers and many others contributed to discussions about the number of races-some recognized hundreds, some only a few. Authors such as Coon et al. (1950) suggested it was just a matter of resolution: Microraces could be defined by a larger number of traits and represented subdivisions of broad major races whose constituents uniquely shared a smaller number of traits. Some of these studies implied the arbitrary nature of racial classification. Coon et al. (1950) wrote on the potential adaptive significance of racial traits. Harry Shapiro (1939) and Fred Hulse (1962), also students of Hooton and interested in questioning the stability of racial traits, demonstrated dramatic morphological changes in first-generation Japanese immigrants in Hawaii, similar to Boas's conclusions earlier in the 20th century. Some students, such as William Sheldon in his famous somatotype studies, retained Hooton's biological determinism (and in Sheldon's case expanded on it); others, such as Coon, inherited Hooton's polygenism; still others, such as Washburn, rejected Hooton's emphasis on race, turning instead to the evolutionary ideas underlying the modern synthesis as the foundation of the new physical anthropology.

With the modern synthesis of the 1940s, Hooton's students also faced the need to bring evolutionary theory into their studies. They did this in different ways. Coon was a typologist who never incorporated populational thinking into his perspective; however, he considered himself an evolutionist, largely through his interest in adaptation. He did not extend this to an understanding of populational processes, a focus on variation within populations, or on the fluidity of populations (Wolpoff and Caspari 1997). The new physical anthropology came to be viewed as the study of human evolution, not the description of human types. Some, like Frederick Hulse, addressed this by looking at races as evolutionary episodes, viewing races as largely ephemeral, caused by evolutionary processes. Washburn sought to develop a new physical anthropology without race, grounded in evolutionary biology and the populational thinking of the synthesis. Only three years after the Princeton symposium that marked the "official" birth of the modern synthesis, Washburn and Dobzhansky organized the famous 15th Annual Cold Spring Harbor Symposium that clarified the evolutionary program of the new physical anthropology. In addition to a focus on human evolution and prehistory, the new physical anthropology espoused ways that biology was relevant to studies of the human condition-that biology and culture could be interrelated without determinism. A new generation of physical anthropologists studied "populations" instead of "races," or studied the distribution of individual traits in clinal studies (Brace 1964).

Ironically, Hooton himself contributed to the changing focus of physical anthropology through his skills as an educator and his respect for his students (Giles 1999). As Harry Shapiro points out in Hooton's obituary in the $A A$, Hooton encouraged diversity of thought in his students. He did not want to establish a "school" and "never attempted to establish intellectual ascendancy over his students" (1954:1082). He encouraged dissenting opinions, telling Shapiro: "You know, none of my students have been yes men. . . Thank God!" (Shapiro 1954:1082). Hooton's students remained diverse, as they established physical anthropology in universities and museums around the country. Some maintained the polygenism and racial approaches of their advisor, while others were responsible, at least in part, for what has been considered the demise of the race concept.

\section{THE DEMISE OF THE RACE CONCEPT?}

\section{Public Science}

The very public rejection of race by many anthropologists in the 1960s was one of a number of responses, beginning in the 1930s, by the scientific community to racism in the larger society. Furthermore, thinking about the race concept itself had evolved with the development of the modern synthesis in biology, and the application of its principles to human variation and evolution (not only by anthropologists but also by the architects of the synthesis itself). Indeed, several of its architects, especially Ernst Mayr (1982, 1991) and Dobzhansky (1944, 1962, 1963) saw the populational thinking of the synthesis and emerging understandings of population genetics to be influential weapons in a war waged by science against public racism. 
However, the reaction sparked by Coon's publication of The Origin of Races was also a response to Coon's tacit alliance with racists seeking to influence public policy (Jackson 2001).

Some anthropologists, as well as other scientists, had been active in antiracism campaigns since the early 1930s. The abuses of biology and anthropology that were at the root of the eugenics movement and Nazi biopolicy propelled at least a few biologists, anthropologists, and evolutionists with a sense of responsibility to present scientific arguments that would undermine this "scientific" racism. This is when Boas and Hooton formed their fruitless coalition to generate support for an antiracist campaign within U.S. academia. The British evolutionary biologist J. B. S. Haldane spoke out against racism at the 1934 London Meeting of the International Congress of Anthropological and Ethnological Sciences (ICAES), warning his audience against the abuse of science in support of race theories. In 1935, responding to rising racism in Europe, Julian Huxley and Alfred Haddon published We Europeans, an important antiracist tract. In addition to undermining biological determinism and assumptions of racial inferiority, they questioned the very existence of race and suggested that ethnic group replace the term race, a harbinger of Ashley Montagu's 1942 Man's Most Dangerous Myth and his 1950 UNESCO statement on race.

Montagu, who received his Ph.D. with Boas at Columbia after studying anatomy with G. Elliot Smith in London, was the U.S. physical anthropologist at the forefront of the public antiracism campaign after the war. He authored numerous popular articles and books, as well as the first UNESCO statement on race, which was very controversial because of his claim that races were a "myth," not because of his denunciation of notions of differences in racial capacities for achievement.

In the 1960s, an even larger group of scientists sought to undermine the scientific racism used to support opponents of the civil rights movement. This reaction was especially strong in the anthropological community. Once again, as in the days of Madison Grant and other times throughout its history, the AAA found itself pitted against groups seeking to influence public racial policy in the name of science. Carleton Putnam and others directly attacked the AAA as a left-wing conspiracy that deliberately concealed the "truth" about race. Coon was squarely in the middle of all this (Jackson 2001), contra the mostly self-generated (Coon 1981) depictions of him as a purely objective scientist whose work was misused by others without his approval (Shipman 1994). As the civil rights movement became stronger and the Supreme Court passed desegregation laws (actively resisted in the South), Coon subtly participated in movements meant to undermine Boasian interpretations of race. Coon was sympathetic to the segregationist cause.

Pamphlets and books such as Race and Reason (1962) by Carleton Putnam (Coon's cousin) used Coon as scientific authority. These publications consciously pitted the subdisciplines of anthropology against each other, claiming that "scientific" anthropologists (like Coon) rejected the dismissal of race and that they had evidence of racial inequality that made blacks undeserving of full citizenship. These writings had wide circulation; they were published in newspapers throughout the South, and there was even a "Putnam Letters Committee" dedicated to raising funds to publish the letters in Northern newspapers, where they appeared as paid advertisements and were used as mass mailings of segregationist propaganda. Moreover, Race and Reason was even required reading in the Louisiana public schools (Jackson 2001)-evidence of its prominence in the South.

Attacks from Putnam and other racists like Henry Garrett (1961) and Wesley George (1962) prompted resolutions on race from both the AAA in November 1961 and the AAPA in 1962. From a press release on the 60th Annual Meeting of the AAA, Gordon Willey, then president of the AAA, called for a resolution in response to "publications on race and racial differences as a basis for social and political action" that used "the name 'anthropology' and 'anthropological science' in a way we believe to be false and misrepresentative of our profession by persons who are not recognized by the American Anthropological Association as professional anthropologists" (Jackson 2001: 263). The resolution passed unanimously.

A few months later, the AAPA passed a resolution introduced by Stanley Garn that specifically condemned Race and Reason and the misuse of science within it. Following the resolution, Coon resigned from the presidency of the AAPA, claiming the resolution was inappropriate and that scientists should keep out of the integration issue (Coon 1981), even though Coon was very active behind the scenes of the segregationist cause through his association with Putnam and others (Jackson 2001).

Some of the authority segregationists cited also came from eugenicists whose work (by the 1960s without the eugenics label) continued to be funded by Wycliffe Draper, founder of the Pioneer fund, and other like-minded sources, which today continues to fund research meant to demonstrate human inequality. This line of research, and its financial foundation, represents a thread running throughout the history of U.S. anthropology (Lieberman 2001) that a few anthropologists have embraced, but that the community at large has consistently repudiated since early in the history of the AAA. Just as the AAA refused to recognize Davenport and Grant as anthropologists in spite of their influence at the time, both the AAA and the AAPA have continued to deny anthropological identity to their intellectual descendents. Like their predecessors, these descendents also claim they are estranged from the field because of the left-wing, political correctness of anthropologists. They use such political claims to deflect criticism of their work (Relethford 2001). Nevertheless, articles "demonstrating" racial inequality continue to be produced and funded by incarnations of the same foundations that supported similar work throughout the century. 
Public attention therefore fostered introspection and discussion about the validity of race within physical anthropology; questions about the intellectual capacities of different racial groups were addressed, as were questions of the "reality" of race. Some individuals rejected at least some elements of the race concept. However, this repudiation of the type concept was more directly influenced by evolutionary biology; because of evolutionary and genetic influences, the newer generation of physical anthropologists grew up thinking about human variation in ways that were not (at least explicitly) racial.

\section{Genetics, Populations, and Clines}

The need to confront public misrepresentations of science that were actively used in the 1960 s fostered alliances between various elements that had fought racism before with some that had not-the architects of the modern synthesis, "mainstream" anthropologists as represented by the AAA, and physical anthropologists as represented by the AAPA. The 1966 AAAS Mead-Dobzhansky symposium represented this alliance, as did a number of volumes on the study of race produced at the time (e.g., Mead et al. 1968; Montagu 1964) that brought together work from a variety of disciplines. One way of attacking racism was (and is) through a focus on the inadequacy of the race concept for explaining human variation. Studies of clines, the geographic distribution of individual morphological and genetic traits, were introduced and population replaced race as a focus of study. This was by no means purely political; it was a consequence of the evolutionary approach of the new physical anthropology.

As C. Loring Brace pointed out in 1964, races, and even populations, are inadequate for the study of human variation. Instead, he advocated for the study of individual traits-the study of their distribution and the selection that causes their variation. The study of clines came to replace race as a focus of analysis for many researchers. Frank Livingstone, in his 1962 article on the nonexistence of human races, eloquently lays out why race or any subspecific taxonomy is misleading:

\begin{abstract}
The causes of intraspecific biological variation are different from those of interspecific variation and to apply the term subspecies to any part of such variation is not only arbitrary or impossible but tends to obscure the explanation of that variation. [1962:279]
\end{abstract}

He was a strong proponent of nonracial clinal studies, arguing, "there are no races, only clines" (Livingstone 1962: 279).

Others, however (e.g., Brues 1972), accepted the importance of clines but argued that the biology of groups themselves was also a valid target of inquiry. With the populational thinking of the modern synthesis, which formed the basis of Washburn's new physical anthropology, populations replaced race as the unit of study. What did this mean? How did the study of populations differ from race? Mayr himself suggests that the populational thinking he developed helped bring about the demise of the race concept, as essentialism is the antithesis to Darwinian approaches to variation. By emphasizing intraspecific evolutionary processes, populational thinking focuses on variation and the fluidity between populations-on all the processes that reduce or increase variation within and between populations. An emphasis on gene flow and its relationship to other evolutionary forces affecting the distribution of different traits across populations is what populational thinking is all about, and it undermined the race concept. The approach is very different from that used to understand phyletic evolution, the focus of many evolutionary scientists, and when populations are studied with theories and methods appropriate for phyletic analyses, the work is no longer populational, but essentialist. When these two very different evolutionary domains are confused with one another, populations are treated much as races once were, and the work does not represent populational thinking.

Therefore, despite the shift in focus from race to population as a unit of study, populational thinking does not necessarily go hand-in-hand with the study of populations. Many 20th-century anthropologists, whether studying genes (Boyd 1950) or morphology, conceived of population as just another term for race. They thought of populations as breeding populations, isolated from other groups. Some recognized this implicitly, some explicitly. Garn wrote, "the contemporary approach to race stems from population genetics, where a race is viewed as a breeding population, neither more nor less" (1962:6). He identified small "local races" like the "Bushmen" of South Africa as more or less isolated breeding populations (Garn 1962). In spite of Washburn's (1963) admonition that races or populations were open systems, populations were nevertheless conceptualized as closed. Therefore, the existence of types was implicit, even if the scientific focus was on their adaptations. As Armelagos, Carlson, and Van Gerven (1982) pointed out, many studies in skeletal biology and genetics continued to employ typological methods to typological ends: the recognition and delineation of populations. Their conclusion in 1982 was that whether using skeletal or genetic traits, many studies of populations are just as typological as studies of race.

In spite of the typological approach of some genetic studies, genetics had a strong influence on the changing race concept, especially the population genetics of the modern synthesis. Population geneticists through the years have provided compelling evidence for human unity. In 1972, when Richard C. Lewontin made famous the estimates of much more variation within than between human groups, he was showing what population geneticists like Dobzhansky had suspected and said all along. While Dobzhansky argued that races were not a "myth," and that there were biological differences between populations, he argued for their fluidity and for the concept of isolation by distance. More recently, Alan Templeton, a geneticist with anthropological training writing in the 
pages of $A A$, looked at race from a genetics perspective, showing that subspecies do not exist in humans and emphasizing that tree models do not adequately describe human population relationships (Templeton 1998).

However, tree models have continued to thrive. As discussed earlier, the polygentc tree was such a powerful metaphor in the thinking of the 1940s and 1950s that Weidenreich's network was originally interpreted as a tree. This historic background continues to influence evolutionary thinking about human populations today.

Relationships between populations are still often depicted as branches on a tree, therefore implying interpopulational differences are due to reproductive isolation from other groups. The magnitude of that difference or the extent of the relationship is sometimes said to reflect the length of time since the populations diverged. Although this is appropriate for species (which cannot interbreed), and may even somewhat accurately depict intergroup relationships in species with marked genetic distinctions between groups, branching models do not describe human relationships. Ironically, the genetic literature is full of such representations. Trees are common heuristic devices used to depict variation of genetic systems. While trees can be valid for representation at this level, they fail to accurately predict population relations if the gene divergences are assumed to reflect the relationships between populations. Worldwide analysis of different genetic systems shows that they have different patterns of variation-that is, their trees have different patterns of branching and coalescence. In the same samples, systems like mtDNA have shallow coalescence times, while others like beta-globin and HLA have much deeper ones (Hawks et al. 2000). Because of recombination, the histories of genes even within the same individual are different. Each gene tree is different because gene histories are not directly linked together in population histories (Harding 2000; Hawks et al. 2000; Relethford 1998). Yet, in much of the genetic literature, a tree derived from a single genetic system is assumed to represent the history of populations.

\section{CONCLUSION}

How did the race concept change in the 1960s? What elements were altered? Can we really celebrate its demise? Of the three attributes of race discussed, biological determinism, or racial determinism of such traits as intelligence, has been most actively addressed since the beginnings of the AAA, and despite misgivings on the part of some cultural anthropologists, the physical anthropology community largely rejects it today. With the growth of evolutionary psychology and behavioral ecology, there may be a resurgence of emphasis on the biological basis of behavioral traits, but, for the most part, these studies recognize the difference between evolutionary foundations and biological determinism.

The link between biological determinism and racial determinism depends on races being natural categories, and physical anthropologists no longer support the notion that races are subspecies. The importance of gene flow and the fluidity of the species is recognized even by forensic anthropologists whose continued use of typological and racially charged terms makes them appear less populational than they often really are. However, in spite of the rejection of races as subspecies, and a reluctance to use the term race, populations are often thought of in much the same way that races were in the earlier literature. Essentialism continues to influence conceptions about human groups, and this is exemplified by the use of trees as metaphors for human population relationships in studies of morphological and genetic human variation. Intraspecific clades are an enduring legacy of racial anthropology and continue to inform our thinking about populations. The race concept may be rejected by anthropology, but its underlying racial thinking persists. Physical anthropologists no longer study races. Populations are now studied, but not all approaches to the study of populations are populational.

RaChel Casparı Department of Anthropology, University of Michigan, Ann Arbor, MI 48109-1382

\section{NOTES}

Acknowledgments. I would like to thank Jim Calcagno for inviting me to participate in this symposium and inspiring me to think about race and physical anthropology in the context of the AAA. I also appreciate the helpful comments of Jim Calcagno, Katarzyna Kaszycka, and an anonymous reviewer. I especially thank Fran Mascia-Lees and the editorial staff of the $A A$ for their excellent suggestions and support.

1. Ultimately, race is a taxonomy of people. It categorizes people based on social factors, even when those factors are believed to represent "natural categories." Because all taxonomies depend on essentializing, essentialism is a critical component of racial thinking. Today, some argue that essentializing is a product of the human mind, suggesting racial thinking may have a psychological component. According to this view, humans create taxonomies of the biological, social, and physical world in similar ways, crossculturally (Atran 1990, 1994; Hirschfeld 1996, 1998). These taxonomies are knowledge structures that allow inferences to be made (beyond the information given) about constituent categories. Some categories are more inferentially rich than others, allowing stereotypes to form without empirical basis. These categories have been termed "natural kinds," because they are believed to be part of the natural world-"real," not human constructions.

"Natural kinds" are produced through different cognitive mechanisms that are specific to particular domains (based on different mental modules). "Natural kinds" that reflect the biological world have been termed "living kinds." People learn "living kinds" through different cognitive processes than those used to learn about inanimate things or the processes that relate to them. Hirschfeld $(1996,1998)$ and others have argued that, in addition to a cognitive domain that governs "living kinds," humans have a separate domain that allows them to easily learn "human kinds" and the complete set of traits that make up the essence of a particular kind. These "human kinds" are social categories that are particularly important to a culture; they are thought by members of that culture to be intrinsic to a person's identity. Just as biological categories carry information about the essence of a species (or a dog breed), "human kinds" carry information about the essence of a type of person-what they are supposed to look like, think like, and act like. The fact that many members of a category do not conform to the stereotype does not dispel the stereotype. "Human kinds" are groups whose members are believed to share some funda- 
mental essence. Because classifications of "human kinds" are considered fundamental reflections of identity, they may have greater social meaning than other categories that do not reflect the essence of a person. In U.S. society, presumed geographic origin and phenotypic features, widely considered the constituent components of race, are considered to be more intrinsic to identity than other categories like occupation or religion. Therefore, in Western society, and globally to some extent because of cultural interconnection, Western dominance, and the legacies of colonialism, "race" is a "human kind" and, therefore, has a psychological dimension since it is based on the same cognitive domain. According to this reasoning, we may be psychologically disposed to racial thinking. This suggests, as Hirschfeld (1996) has said, that racial thinking and the race concept are not one and the same; the race concept may be a product of "mentation," but racial thinking is cultural and psychological.

\section{REFERENCES CITED}

Armelagos, George J., David S. Carlson, and Dennis P. Van Gerven

1982 The Theoretical Foundations and Development of Skeletal

Biology. In History of American Physical Anthropology

1930-1980. Frank Spencer, ed. Pp. 305-328. London: Academic Press.

Atran, Scott

1990 Cognitive Foundation of Natural History. New York: Cambridge University Press.

1994 Core Domains vs. Scientific Theories: Evidence from Systematics and Itza-Maya Folk Biology. In Mapping the Mind. L. Hirschfeld and S. Gelman, eds. Pp. 316-340. Cambridge: Cambridge University Press.

Barkan, Elazar

1988 Mobilizing Scientists against Nazi Racism, 1933-1939. In Bones, Bodies, Behavior. Essays on Biological Anthropology. G. W. Stocking Jr., ed. Pp. 180-205. Madison: University of Wisconsin Press.

Boas, Franz

1894 Human Faculty as Determined by Race. Proceedings of the American Association for the Advancement of Science 43:301-327.

1974 The Shaping of American Anthropology, 1883-1911: A Franz Boas Reader. New York: Basic Books.

Boyd, William Clouser

1950 Genetics and the Races of Man. Boston: Little, Brown.

Brace, C. Loring

1964 A Nonracial Approach towards the Understanding of $\mathrm{Hu}$ man Diversity. In The Concept of Race. M. F. Ashley Montagu, ed. Pp. 103-152. New York: Free Press.

1982 The Roots of the Race Concept in Physical Anthropology. In A History of American Physical Anthropology 1930-1980. Frank Spencer, ed. Pp. 11-29. London: Academic Press.

Brues, Alice

1972 Models of Clines and Races. American Journal of Physical Anthropology 37:389-399.

Caspari, Rachel, and Milford $\mathrm{H}$. Wolpoff

1996 Coon and Weidenreich. Human Evolution 11:203.

Cole, Douglas

1999 Franz Boas: The Early Years, 1858-1906. Seattle: University of Washington Press.

Coon, Carleton S.

1939 The Races of Europe. New York: MacMillan.

1950 Human Races in Relation to Environment and Culture, with Special Reference to the Influence of Culture upon Genetic Changes in Human Evolution. Cold Spring Harbor Symposium on Quantitative Biology 15:247-258.

1962 The Origin of Races. New York: Knopf.

1965 The Living Races of Man. New York: Knopf.

1981 Adventures and Discoveries. The Autobiography of Carleton S. Coon. Englewood Cliffs, NJ: Prentice-Hall.

Coon, C. S., S. M. Garn, and J. B. Birdsell

1950 Races: A Study of the Problems of Race Formation in Man. Springfield, IL: C. C. Thomas.

Dixon, Roland B.

1923 The Racial History of Man. New York: Scribner.
Dobzhansky, Theodosius

1944 On Species and Races of Living and Fossil Man. American Journal of Physical Anthropology 2:251-265.

1962 Mankind Evolving: The Evolution of the Human Species. New Haven, CT: Yale University Press.

1963 Possibility That Homo sapiens Evolved Independently 5

Times Is Vanishingly Small. Current Anthropology 4:360-366.

Garn, Stanley M.

1957 Race and Evolution. American Anthropologist 59:218-224.

1962 Human Races. Rev. edition. Springfield, IL: C. C. Thomas.

Garrett, Henry E.

1961 The Equalitarian Dogma. Perspectives in Biology and Medicine 4:480-484.

Gasman, Daniel

1971 The Scientific Origins of National Socialism: Social Darwinism in Ernst Haeckel and the German Monist League. New York: Elsevier.

Gates, R. Ruggles

1944 Phylogeny and Classification of Hominids and Anthropoids. American Journal of Physical Anthropology 2:279-292.

George, Wesley C.

1962 The Biology of the Race Problem. Washington, DC: National Putriam Letters Committee.

Giles, Eugene

1999 Hooton, Earnest Albert. In American National Biography, vol. 11. Pp. 147-149. John A. Garaty and Mark C. Carnes, eds. New York: Oxford University Press.

Haeckel, Ernst

1905 The Wonders of Life. New York: Harper.

Harding, Rosalind $M$.

2000 Diversity, Not Divergence. Genetic History of Modern Humans. 8th CEPH Annual Conference, Faculte de Medicine Lariboisiere Saint-Louis, Paris, May, 24-26, 2000. Trends in Genetics $16: 381$.

Hawks, John, Keith Hunley, Sang-Hee Lee, and Milford H. Wolpoff 2000 Bottlenecks and Pleistocene Human Evolution. Molecular Biology and Evolution 17:2-22.

Hirschfeld, Lawrence A.

1996 Race in the Making: Cognition, Culture and the Childs Construction of Human Kinds. Cambridge, MA: MIT Press.

1998 Natural Assumptions: Race, Essence and Taxonomies of $\mathrm{Hu}$ man Kinds. Social Research 65(2):331-350.

Hirschfeld, Lawrence A., and Susan A. Gelman, eds.

1994 Mapping the Mind: Domain Specificity in Cognition and Culture. New York: University of Cambridge Press.

Hooton, Earnest A.

1931 Up from the Ape. New York: MacMillan.

1936 Plain Statements about Race. Science 83:511-513.

1937 Apes, Men, and Morons. New York: G. P. Putnam.

1939 Twilight of Man. New York: G. P. Putnam.

Howells, William W.

1942 Fossil Man and the Origin of Races. American Anthropologist 44:182-193.

1959 Mankind in the Making. Garden City, NJ: Doubleday.

1993 Getting Here. The Story of Human Evolution. Washington, DC: Compass Press.

Hulse, Frederick $S$.

1962 Race as an Evolutionary Episode. American Anthropologist 64:929-945.

Huxley, Julian S., and Alfred C. Haddon

1935 We Europeans: A Survey of "Racial" Problems. London: Jonathan Cape.

Jackson, John P., Jr.

2001 "In Ways Unacademical": The Reception of Carleton S. Coon's The Origin of Races. Journal of the History of Biology 34:247-285.

Keith, Arthur

1936 History from Caves. A New Theory of the Origin of Modern Races of Mankind. London: British Speleological Association Publication.

Lewontin, Richard C.

1972 The Apportionment of Human Diversity. Evolutionary Biology 6:381-398. 
Lieberman, Leonard

2001 How "Caucasoids" Got Such Big Heads and Why They Shrank: From Morton to Rushton. Current Anthropology 42:69-95.

Linnaeus, Carolus

1758 Systemae Naturae. 10th edition. Stockholm: Laurentii Salvii.

Livingstone, F. B.

1962 On the Non-Existence of Human Races. Current Anthropology 3:279-381.

Mayr, Ernst

1982 The Growth of Biological Thought: Diversity, Evolution, and Inheritance. Cambridge, MA: Belknap Press of Harvard University Press.

1991 One Long Argument: Charles Darwin and the Genesis of Modern Evolutionary Thought. Cambridge, MA: Harvard University Press.

Mead, Margaret, Theodosius Dobzhansky, Ethel Tobach, and

Robert E. Light, eds.

1968 Science and the Concept of Race. New York: Columbia University Press.

Montagu, Ashley

1942 Man's Most Dangerous Myth: The Fallacy of Race. New York: Columbia University Press.

Montagu, Ashley, ed.

1964 The Concept of Race. New York: Free Press.

Morgan, Lewis Henry

1964[1877] Ancient Society. Cambridge, MA: Harvard University Press.

Putnam, Carletor

1962 Race and Reason: A Yankee View. Washington, DC: Public Affairs Press.

Relethford, J. H.

1998 Genetics of Modern Human Origins and Diversity. Annual Review of Anthropology 27:1-23.
2001 Comment on Lieberman, L. How "Caucasoids" Got Such Big Heads and Why They Shrank: From Morton to Rushton. Current Anthropology 42:84-85.

Shapiro, H. L.

1939 Migration and Environment. New York: Oxford University Press.

1954 Earnest Albert Hooton, 1887-1954. American Anthropologist 56:1081-1084.

Shipman, Pat

1994 The Evolution of Racism: Human Differences and the Use and Abuse of Science. New York: Simon and Schuster.

Stanton, W.

1960 The Leopard's Spots: Scientific Attitudes toward Race in America 1815-59. Chicago: University of Chicago Press.

Stein, George J.

1988 Biological Science and the Roots of Nazism. American Scientist 76:50-58.

Stocking, George W., Jr.

1968 Race, Culture, and Evolution: Essays on the History of Anthropology. New York: Free Press.

Templeton, Alan R.

1998 Human Races: A Genetic and Evolutionary Perspective. American Anthropologist 100:632-650.

Washburn, Sherwood L.

1963 The Study of Race. American Anthropologist 65:521-532.

Weidenreich, Franz

1940 Some Problems Dealing with Ancient Man. American Anthropologist 42(3):375-383.

1946 Apes, Giants, and Man. Chicago: University of Chicago Press. 1947 Facts and Speculations Concerning the Origin of Homo sapiens. American Anthropologist 49:187-203.

Williams, Vernon J., Jr.

1996 Rethinking Race: Franz Boas and His Contemporaries. Lexington: University Press of Kentucky.

Wolpoff, M. H., and R. Caspari

1997 Race and Human Evolution. New York: Simon and Schuster. 